\title{
ACCESS TO JUSTICE AND ADMINISTRATION OF LEGAL CONFLICTS: FROM THE SENTENCE CULTURE TO A CONSENSUAL CULTURE
}

\author{
ACESSO À JUSTIÇA E GESTÃO DE CONFLITOS JURÍDICOS: DA CULTURA DA \\ SENTENÇA PARA UMA CULTURA DO CONSENSO
}

Adriana Silva Maillart

Pós-doutora, Doutora e Mestre pela Universidade Federal de Santa Catarina (UFSC); Bacharel em Direito pela Universidade de Passo Fundo (UPF).

Email: adrissilva@gmail.com

\section{Ricardo Soares Stersi dos Santos}

Pós-doutor pela Universidade Federal de Pernambuco (UFPE) e pela Universidade Católica do Paraná (PUC-PR); Doutor e Mestre pela Universidade Federal de Santa Catarina (UFSC);

Professor da Graduação e do Programa de Pós-graduação em Direito da Universidade Federal de Santa Catarina (UFSC).

Email: rstersi@hotmail.com

\section{Jéssica Gonçalves}

Doutoranda e Mestre em Direito pela Universidade Federal de Santa Catarina (UFSC); Especialista em Direito Processual Civil pela Universidade Federal de Santa Catarina (UFSC); Especialista em Direito Público e em Direito Aplicado pela Universidade Regional de Blumenau (FURB).

Email: jessic.goncalves@ hotmail.com

Recebido em: 10/09/2018

Aprovado em: 01/03/2019

\begin{abstract}
The purpose of this article is to analyze, within the prism of the innovations proposed by the Judiciary Reform, with the creation of National Justice Council (Conselho Nacional de Justiça - CNJ) and specific guidelines for the creation of alternative means to the Judiciary, why the sentence culture is perpetuated as a paradigm of resolution of conflicts, to the detriment of the culture of consensus. To do so, we analyze the origin of the conflict, the specificities of the sentence and consensus cultures, and then establish the main obstacles to the substitution of the culture of the sentence by a consensual culture of conflict management. This paper adopts the hypothetical-deductive method of research and the documentary and bibliographic review, as a research technique.
\end{abstract}


Keywords: Access to Justice; Conflict Management; Alternative Dispute Resolution (ADR); Sentence Culture; Consensual Culture.

RESUMO: Este artigo tem por objetivo analisar, dentro do prisma das inovações propostas pela Reforma do Judiciário, com a criação de CNJ e de diretrizes específicas para a criação de meios alternativos ao Poder Judiciário, o porquê da perpetuação da cultura da sentença, como paradigma de resolução de conflitos, em detrimento da cultura do consenso. Para tanto, analisa-se a origem do conflito, a especificidades das culturas da sentença e do consenso, para posteriormente estabelecer os principais entraves para a substituição da cultura da sentença por uma cultura consensual de administração dos conflitos. Este artigo adota o método hipotético-dedutivo de pesquisa e a revisão documental e bibliográfica, como técnica de pesquisa.

Palavras-chaves: Acesso à Justiça; Gestão de Conflitos; Resolução Alternativa de Disputa; Cultura da Sentença; Cultura do Consenso.

SUMMARY: Introduction; 1 The conflict; 2 "Consensual Culture" and the self-applied forms of dispute resolutions; 3 The "sentence culture" and its inferences; 4 The obstacles to replacing the "sentence culture" with a "consensual culture"; Conclusion; References.

\section{INTRODUCTION}

As seen in the Report on Justice in Numbers, carried out by the National Justice Council (Conselho Nacional de Justiça - CNJ) ${ }^{1}$, legal conflicts are multiplying in Brazil, making access to justice more distant for the vast majority of the population.

Although efforts are being made to establish other means of dispute settlement in Brazil, a system of justice, which concentrates on judicial processes the primacy of the way of administering legal disputes, is still in place. This situation brands the "sentence culture" the paradigm of conflict resolution in Brazil since its colonization by Portugal.

Resolution $n^{\circ} 125$ of 2010 of the National Council of Justice (CNJ), Law $n^{\circ} 13105$ of March 16, 2015 (New Code of Civil Procedure) and Law no 13.140 of June 26, 2015 (Law of Mediation) are examples of the intention to change the justice system, shifting the primacy of the adjudicated decision (sentence) to the consensual decision (agreement). However, it remains to be seen whether these administrative and legislative efforts will be sufficient to modify a culture of conflict management that has been consolidated in the utterance of sentences and reproduced over the last 500 years.

Therefore, using the hypothetical-deductive method of approach and the bibliographic and documentary revision, as a research technique, it'll analyze the basic traits of the origin of the conflict, to point out the characteristics of the "sentence culture" and "consensual culture" by tracing the differences between the existing and desired models and finally establishing some of

\footnotetext{
1 Relatório Justiça em Números $2017 . \quad$ Available <http://www.cnj.jus.br/files/conteudo/arquivo/2017/09/904f097f215cf19a2838166729516b79.pdf>. Access in: $09 / 10 / 2017$.
} 
the main obstacles to replacing the "sentence culture" with a "consensual culture" of conflict management.

\section{THE CONFLICT}

Conflict is part of people's daily lives. Even in Utopian Societies, it doesn't exist only social relations of cooperation among its members ${ }^{2}$. Because each social action will be assigned certain meanings by the individuals involved and social actions are practiced in order to meet the goals sought by each of the actors involved in the social relationship. Conflict and cooperation are ways of relating in life in Society ${ }^{3}$ and the conflict arises when there is the awareness of the actors that the behaviors of others prevent them from fulfilling their goals.

However, defining conflict is not an easy task, since this concept presents different traits in each theoretical model used to analyze the phenomenon. Nowadays, conflict has a multidisciplinary facet.

From a sociological matrix, conflict exists when "[...] the chance of a man or of a number of men to realize their own will in a communal action even against the resistance of others who are participating in the action". (WEBER, 2002, p. 67)

Making the distinction between the sociological and the psychological matrix of the conflict, Olguín (2002, p.15) recognizes that in the field of psychology, conflict represents a coexistence of contradictory perspectives in the individual. It is a confrontation that occurs within the consciousness of an individual about the choice of options that are generated from a set of options represented as competing desires.

Mitchell (1989, p.35) recognizes the difference between conflicts of interests and (ideological) values. In the first case, the conflict stems from the differences between the parties on the distribution of some scarce resource to which each party attributes a high value. In the second case, conflict exists because each part has different beliefs, different values stemming from its own culture, diverse social organization, etc.

For Caivano, Gobbi and Padilla (1997, p. 117):

[...] conflict manifests itself as an intersubjective contradiction of law and obligations, as a phenomenon that occurs when two common claims coexist in relation to the same good, or rather a pretension on the one hand and resistance on the other ${ }^{4}$.

And from the perspective of Entelman (2005, p. 49) ${ }^{5}$ :

\footnotetext{
${ }^{2}$ Reference to The City of the Sun by Tommaso Campanella, Utopia by Tomas More and Brave New World by Aldous Huxley.

3 “[...] a situação em que duas ou mais pessoas estão empenhadas numa conduta onde cada qual leva em conta o comportamento da outra de uma maneira significativa, estando, portanto, orientada nestes termos. A relação social consiste, assim, inteiramente na probabilidade de que os indivíduos comportar-se-ão de uma maneira significativamente determinável". Weber, 2002, p. 45.

4 “[...] o conflito se manifesta como uma contraposição intersubjetiva de direito e obrigações, como um fenômeno que se produz quando a respeito de um mesmo bem coexistem duas pretensões conjuntas, ou melhor, uma pretensão por um lado e uma resistência por outro". Caivano; Gobbi; Padilla, 1997, p. 117.

5 "Serán relaciones de conflicto cuando sus objetivos sean incompatibles o, como veremos después, todos o algunos miembros de la relación los perciban como incompatibles. Cuando los objetivos no sean total o parcialmente incompatibles, sino comunes o coincidentes, tendremos relaciones de 'acuerdos' que, en lugar de conductas conflictivas, generán 'conductas cooperativas' o 'conductas coincidentes' que pueden ser individuales o colectivas". Entelman, 2005, p. 49.
} 
They will be relations of conflict when their objectives are incompatible or, as we will see later, all or some members of the relationship perceive them as incompatible. When the objectives are not totally or partially incompatible, but common or coincidental, we will have relationships of "agreements" that, instead of conflicting behaviors, generate "cooperative behaviors" or "coincident behaviors" that can be individual or collective.

In Law, the legal norms are the main models of conduct of the agents, fomenting the expectations of actions related to the conducts admitted by the legal order. Thus, according to Arnaud and Dulce (2000, p. 149), the first function of law would be the resolution of conflicts. "This means that law identifies, organizes and resolves conflicts that could disturb the balance and social order", that is, "the law has as its mission to restore social peace and balance, when conflicts of interest disturb them" (Arnaud, Dulce, 2000, p.149). However, the authors (Arnaud; Dulce, 2000, pp. 149-150) argue that:

If one starts from the premise that, in the functioning of society, conflict is permanent, that is, that social interaction is inevitably conflictual, it is necessary to admit that law does not resolve conflicts in the functionalist sense that the conflict disappears from social conflict. The only thing that the law can aspire to is to give a legal treatment to possible conflicts of interests antagonistic between the parties.

[...] the "conflict" itself, however, does not disappear from the social structure; his right is appropriated, at the moment in which he proposes a possible "treatment". The law does not constitute an order of peace, but lives in and of "conflict." If the "social conflicts" disappeared altogether, the law would disappear as well ${ }^{6}$.

In agreement as seen above, in the perspective of this research, it prefers to adopt the expression administration of the conflicts, for understanding that the conflicts are natural the life of the society and they need to be administered, more than solved.

For the administration of conflicts, a number of ways were created and accepted by the state in order to restore social peace. The best known is the Judicial Power, proclaimed by the sentence culture, which will be analyzed below.

However, the modern perspective of access to justice is not limited to access to the judiciary, but to a series of socially accepted mechanisms that are capable of continuously promoting social pacification. Even more, as Arnaud and Dulce (2000, p. 150) refer, the judicial process is an example of how "law not only" resolves conflicts "in the ordinary sense of the term but can also provoke them".

Thus, other mechanisms parallel to the judiciary arise in recent decades, whose social pacification occurs not through the decision awarded to a third party, but through procedures that highlight the decision-making power of the interested parties through agreement, named here as consensual culture.

\footnotetext{
6 "Se se parte da premissa segundo a qual, no funcionamento da sociedade, o conflito é permanente, isto é, que a interação social é inevitavelmente conflituosa, é preciso, então, admitir que o direito não resolve os conflitos no sentido funcionalista que quer que o conflito desapareça do conflito social. A única coisa a que o direito pode aspirar é dar um tratamento jurídico aos possíveis conflitos de interesses antagônicos entre as partes. [...] o "conflito" em si, entretanto, não desaparece da estrutura social; o direito dele se apropria, no momento em que ele propõe um "tratamento" possível. O direito não constitui uma ordem de paz, mas vive no e do "conflito". Se os "conflitos sociais" desaparecessem totalmente, o direito desapareceria também". Arnaud; Dulce, 2000, p. 149-150.
} 


\section{2 "CONSENSUAL CULTURE" AND THE SELF-APPLIED FORMS OF DISPUTE RESOLUTIONS}

The "consensual culture" is configured as the beliefs, practices, values and institutions geared to the administration of legal conflicts in which the main role of who is involved in the conflict is emphasized in the construction of a dialogue that can lead to a responsible agreement to finally the differences between them. In the "consensual culture", conflicts are pacified by decision of the interested of the parties (agreement) and not by the adjudicated decision of third parties (sentence).

In the discursive logic of the "consensual culture", the justice system needs to be modified to encourage the parties to take responsibility for solving their own conflicts of interest by the agreement, using adjudicated decisions only in cases where are unable to establish a dialogue or are unable to adjust their own differences through it.

It implies, therefore, the establishment of a chronological criterion in which, first, it emphasizes the search for consensually constructed solutions (agreements) and then, in a second moment, to visualize the path of the adversarial and imposing solutions (sentences).

It is not just the individual conflicts that will be objects of the "consensual culture". There are a number of dialogic methods of conflict management that address collective conflicts and refer to the "consensual culture", such as mediation, ombudsman, among others.

The "consensual culture" should also encourage the use of consensual approaches (selfapplied dispute resolution) before the use of adversarial means. And even in cases that the heterocomposition are used to, this procedure should, at any moment, stimulate the parties to seek dialogued solutions.

For Grinover (2016, p. 65-66), conciliative justice, such as negotiation, mediation and conciliation, among others, is based on: a) social pacification; b) the participation of the interested parties in the solution of the conflicts, typical of participatory democracies, c) the unlocking of the judicial courts.

Consensual forms are those in which the parties, with or without the cooperation of a third party, seek to resolve the conflict directly through a result constructed by the parties themselves (agreement).

The main characteristics of self-applied forms ${ }^{7}$ are the will of the agents in the choice of the form of resolution of the conflict, of the procedure and the power of the parties themselves to put an end to the conflict. They have the power to decide, for example, whether they will make a deal and, if they do it, they will set their terms. The most foreseeable result arising from the use of consensual forms is the agreement.

\footnotetext{
${ }^{7}$ It's known as self-applied forms of dispute resolutions: among others, negotiation, mediation, conciliation, rent a judge, ombudsman.
} 


\section{THE "SENTENCE CULTURE" AND ITS INFERENCES}

Shirley (1987, p.5) points out that all humans grow up experiencing at least one culture and, usually, they are embedded in ethnocentrism ${ }^{8}$. Culture means "[...] the set of knowledge, beliefs and values of a society".

As well as the expression of a culture, a social group establishes mechanisms capable of achieving justice, promoting the administration of social conflicts and restoring social peace.

If, in the first instance, these mechanisms are instruments of socially accepted values such as justice, order, security, among others, the social culture itself eventually becomes incorporated. This is what happened with the use of the judicial form (trial by judges) that, gradually in Brazil, as in other western countries, became the preponderant means of administering legal conflicts.

Thus, the term "sentence culture" seeks to designate a socially established and accepted belief that the most effective way to promote the realization of legally protected values and to achieve social peace is through adjudicated actions and decisions (sentences) delivered by the judges.

It is not one of the objectives of this research to analyze how the culture was historically built in Brazil. It is known, however, that such culture was brought to Brazil during the colonization by Portugal. At that moment, the implantation of the model that, later became a cultural parameter of conflict management, was begun and that it continued to be reproduced even after Brazil had become an independent state.

Highton and Alvarez (1998, p. 99), defining the model of conflict management through judicial process, point out that, "the judicial process is fact, a debate between lawyers where the parties, in the substance, are excluded and in which, finally, a third party - the judge - makes the decision that is obligatory for them",

For Watanabe (2007, p. 07), in Brazil there is a "sentence culture" since, "judges prefer to pronounce sentence instead of trying to conciliate the parties to obtain a friendly solution of conflicts".

It is also impossible to think of a "sentence culture" without taking into account the economic, political, sociological, anthropological and psychological factors, among others, that influenced the establishment of the cultural pattern of seeking the satisfaction of legally protected objectives through judicial process and the judgment.

In such a way that the model developed in Brazil and based on the "sentence culture" is the object of several criticisms.

For Lima Filho (2003, p. 278) ${ }^{10}$ :

\footnotetext{
${ }^{8}$ The sense of ethnocentrism is "[...] the idea that one's own culture and beliefs are 'the truth' or at least the superior way of dealing with the world". SHIRLEY, 1987, p.05.

9 "El proceso judicial es más que nada, un debate entre abogados donde las partes, en lo substancial, quedan excluidas y en el cual, finalmente, un tercero - el juez - toma la decisión que es obligatoria para ellas". Highton; Alvarez, 1998, p. 99.

10 "O uso, quase que exclusivo, do processo jurisdicional estatal para solução dos conflitos - resultado de uma cultura jurídica extremamente dogmática, que vê na lei estatal praticamente a única fonte de direito -, tem provocado custos não apenas econômicos para os que se valem do processo, como também um sentimento de angústia social e frustração para aqueles que deixam de buscar seus direitos e a solução de seus conflitos gerados pelo não atendimento de seus interesses, frente às, quase intransponíveis, dificuldades para as camadas menos favorecidas da população, o que motiva o cidadão a desiludir-se com o que costuma chamar de 'justiça' ". Lima Filho, 2003, p. 278.
} 
The almost exclusive use of the state judicial process for resolving conflicts - the result of an extremely dogmatic legal culture, which sees in state law virtually the sole source of law - has caused not only economic costs for those who use the process, as well as a sense of social anguish and frustration for those who fail to seek their rights and the solution of their conflicts generated by the non-fulfillment of their interests, facing the almost insurmountable difficulties for the less favored sections of the population, which motivates the citizen to become disillusioned with what he usually calls "justice".

\section{According Calmon (2007, p. 03) ${ }^{11}$ :}

The called 'crisis of justice' occupies growing space in the political and academic agenda. Society, in many countries, shows that it is dissatisfied with the public service of justice, which does not adequately meet its needs, both in civil and criminal matters. It complains of the absence of justice or of his tardiness, as well as of the ineffectiveness of its decisions. Solving this problem is a challenge to be overcome in a complex and coordinated way, and it is not wise to expect that one initiative will serve as a panacea for such deeply entrenched evils.

Grinover (2007, p. 22) mentions that the justice service provided in Brazil, where the judicial process prevails, is in crisis due to delay, bureaucratization, cost, mentality of the judges, lack of adequate information consumers of justice, problems in the gratuitousness of the process that, among other aspects, increase the distance between the judges and the society.

Research data from the Confidence Index in Brazil (ICJ Brasil) on the credibility and satisfaction of the population regarding the service of justice provided by the Judiciary in Brazil, prepared by the Getúlio Vargas Foundation and gathered in eight (8) States of the Federation of first half of 2016, indicate that only twenty-nine percent (29\%) of the population believes and is satisfied with the work of the judges, even though forty-six percent $(46 \%)$ consider the judges truthful. (ICJ BRASIL, 2016, p.15-17)

Also, it was high the percentage of respondents who had already (personally or someone residing at home) entered with at least one legal process to achieve legally protected goals.

According to the Index of Confidence in Brazilian Justice (ICJ Brasil, 2016, p.16), the percentage of lawsuits filed in the judicial system in relation to the salary level is as follows: 1) up to a minimum wage: thirty-two percent $(32 \%)$; 2) from one to four minimum wages: forty percent $(40 \%)$; 3) from four to eight minimum wages: thirty seven percent $(37 \%)$; 4) above eight minimum wages: forty percent $(40 \%)$.

Likewise, in ICJ Brasil (2016, p.14) it is possible to identify the dissemination of the "sentence culture" among the population. In cases involving conflicts of consumption, labor relations, neighborhood, relations with the public administration, service provision and family issues, eighty percent ( $80 \%$ ) of the interviewees would seek the Judiciary (and the judicial process) as a tool to manage such conflicts. Regarding consumer relations, the numbers are alarming, which $92 \%$ of those interviewed seeking the Judiciary.

\footnotetext{
11 “A denominada 'crise da justiça' ocupa espaço crescente na agenda política e acadêmica. A sociedade, em muitos países, demonstra estar insatisfeita com o serviço público de justiça, que não atende adequadamente às suas necessidades, tanto na área cível como na penal. Queixa-se da ausência de justiça ou da sua morosidade, bem como da ineficácia de suas decisões. Resolver esse problema é um desafio a ser vencido de forma complexa e coordenada, não sendo sábio esperar que uma só iniciativa venha servir de panaceia para males tão fortemente enraizados". Calmon, 2007, p. 03.
} 
The data of the ICJ Brazil reflects in the search of the parties by the process and the sentence that overloads the justice system with the most varied types of claims, whether these are reasonable or not. As an example of this unreasonable judicialization, there are news of a person who sought the Judiciary for a sentence that determined that the Unified Health Service (SUS) paid for the bill of a high-cost drug for his pet $\operatorname{dog}^{12}$.

From the above mentioned ICJ Brazil data, it is possible to understand the inertial force of the pattern referred to as "sentence culture" after all, the same interviewees who suspect of the Judiciary institution cannot see another way of managing their legal conflicts except by adjudicated decision delivered by a judge.

The contradiction identified above is reflected in the numbers of the "sentence culture" in Brazil.

According to the CNJ's 2017 report for 2016, justice expenses in Brazil increased from 51.2 billion reais in 2009 to 84.8 billion reais in 2016, with 48.1 billion reais spending on states justice. The value of spending corresponded to $1.4 \%$ of the Gross Domestic Product (GDP) and the cost of justice per capita in Brazil was R \$ 315.52 in 2009 to R \$ 411.73 in 2016.

79.7 million lawsuits were processed in Brazil in 2016, compared to 59.1 million in 2009. Even though, in 2016, 29.4 million lawsuits were finalized by judgment, in the same year another 29.4 million lawsuits were filed.

The number of judges increased from 15,946 in 2009 to 18,011 (including the highest courts) in 2016. In 2016, the Judiciary had 279,013 employees and 145,321 auxiliary workers. Of these auxiliary workers, approximately 10,000 are conciliators/ mediators.

The conciliators and judicial mediators are technical servants of the Judiciary itself who are displaced from their administrative functions to act as conciliators and mediators, especially in the courts, as well as persons outside the Judiciary who act as conciliators and voluntary mediators.

Although the numbers of cases completed in 2016 are relevant, it is necessary to understand that the judges currently work with established goals (which impact promotions of magistrates) and to comply with them, some use working hours that cannot be verified in the CNJ statistics.

For the year 2017, seven goals were determined, among them: a) to judge more processes than those distributed; b) judge older processes ${ }^{13}$.

One of the ways some judges found to accomplish the goals was to group a series of processes related to subjects of less complexity or referring to repetitive demands and to focus on deciding these processes. Thus, many sentences can be obtained without the stock of new and older processes of greater complexity being analyzed (postponing their analysis for an indefinite future). Prioritizing, therefore, the quantity in relation to the quality. Another strategy used is to issue procedural sentences that promote the termination of the process without resolution of merit.

In the $\mathrm{CNJ}$ report, it is also possible to identify the main litigants responsible for excess litigation (active and passive demands) in Brazil, being the largest litigant the State itself (Union, States and Municipalities), followed by the Banks and Telephony (mobile and fixed). ${ }^{14}$

\footnotetext{
12 COLUCCI, Claudia. Família pede na justiça que SUS dê remédio de alto custo para cadela. Available in: http://www1.folha.uol.com.br/cotidiano/2016/09/1810929-familia-pede-na-justica-que-sus-de-remedio-caro-paracadela-doente.shtml. Access in:09/24/2017.

13 The goals and results of 2017 released by the National Justice Council (CNJ) are available at http://www.cnj.jus.br/gestao-andplanjamento/metas, accessed on 09/27/2017.

${ }^{14}$ Data pointed out by the National Justice Council (CNJ) and available at http://www.cnj.jus.br/images/pesquisasjudiciarias/pesquisa_100_maiores_litigantes.pdf, accessed on 09/27/2017.
} 
By such numbers it is possible to make a portrait and have a dimension of the cost of the current model of primacy of the decision adjudicated by a judge. The model is criticized in several aspects for its slowness, formality, effectiveness, etc.

Although it seeks to correct some of the deviations from the current model known as "sentence culture" through reforms in the judicial process, including the adoption of a new civil procedural law, there is a dissatisfaction with the results produced by the model itself that empowers the Judicial system to the detriment of individuals and social groups (Civil Society).

From this collective dissatisfaction in Brazil, CNJ Resolution n. 125 supported a possibility of changing the justice system: from the primacy of the "sentence culture" to a "culture of consensus", increasing the importance of consensual methods in and emphasizing the importance of this transformation.

It is well-known, the construction of the "sentence culture" did not take place overnight, and this will not happen with the incorporation of a new model that emphasizes the participation of the interested parties themselves in the solution of conflicts.

\section{THE OBSTACLES TO REPLACING THE "SENTENCE CULTURE" WITH A "CONSENSUAL CULTURE"}

In order to transform the current "sentence culture" model into a new one, based on the "consensual culture", a series of primarily educational measures will have to be adopted, in addition to the adjustments established in CNJ Resolution 125.

Recent laws, such as the Special Courts (Law n. 9099/95), Arbitration (Law n. 9307/96 and Law n. 13129/15), the New Code of Civil Procedure (Law n. 13105/15) and Mediation (Law n. 13140/15), aim to help this transformation of culture by recognizing and giving greater importance to other modes of conflict management (especially those arising from the consensus of the parties) and not only to the judicial process.

However, such legislation alone does not educate the parties to seek the satisfaction of their interests other than through the traditional judicial process. A series of changes, especially in the education of people, have to be implemented, to be applied over a long period of time, so that the current model will become a broader culture of conflict management.

The obstacles to the development of a "consensual culture" can be classified into two distinct orders: institutional and personal.

Institutional obstacles are those produced by structures and by repeated, stable and socially recognized behaviors. These are impediments practiced by educational, religious, political, social and legal institutions, among others, which create obstacles to the possibility for the parties themselves to take the decision regarding their conflict of interests.

Personal obstacles are those arising from the conflict of conscience of individuals that prevent them from changing their own behavior in the management of conflicts.

Identifying the institutional or personal obstacles, it is necessary to establish a planning of the actions necessary to overcome such obstacles that precisely allow the maintenance of the culture associated with the "status quo".

Among the suggested actions to overcome the obstacles can be highlighted:

1) the education of the agents of the Judiciary itself on the need to transform the current model by another in which the parties themselves take the lead, controlling the procedure and deciding the conflict. Such action is already supported by legislation and requires, as provided in resolution 125, a series of training courses for the agents of the Judiciary to know, incorporate and 
eventually enable the use of consensus techniques of conflict management, either through mediation or conciliation, pre-procedural or endo-procedural (within the process).

The education of the consensual means of administering conflicts to the public agents of the Judiciary (judges, servants and auxiliaries) is one of the necessary steps to break resistance to a transformation of culture.

The courses offered by the Courts of Justice for the training and updating of judicial mediators and conciliators should seek to accomplish, in addition to the workload provided for in CNJ Resolution 125, levels of quality and excellence that allow a real training of these auxiliaries of justice (and not a mere appearance of training). It is necessary to pay attention to the quality of the courses that are offered.

It is even known that the mere formation of agents (mediators and conciliators) in such courses does not necessarily create a mass of mediators and conciliators capable and able to act adequately in the use of consensual mechanisms. In each course of training, updating and practical activities, over time, it will be possible to identify the agents who have the necessary expertise to act as mediator or conciliator. It is necessary to construct mechanisms that separate those who formally carried out the training of those who, after training, demonstrate the necessary skills to act as mediator or as conciliator.

Since not all those who have taken the training courses will have the skills to be conciliators or mediators, as well as, not all those who have graduated in legal courses can act as lawyers, judges, prosecutors etc.

It is also necessary to create mechanisms of attraction so that the "true" mediators and conciliators can develop their abilities. One of them is the establishment of good private and public chambers of mediation and conciliation that can offer their services to the interested parties both in the pre-procedural and in the endo-procedural sphere and that are remunerated by the parties themselves or by the State, depending on the situation. The State of São Paulo already has legislation (Law 15804/15) that regulates the working day and the remuneration of the mediators and conciliators that compose the Cejuscs' staff, despite restricting the paid work in 16 hours a week (the number of overtime is computed as voluntary activities). ${ }^{15}$

Another important mechanism is the creation of own careers of mediator and judicial conciliator, to be filled by public tender process either in partial or full time. In this way, the Judiciary would have its own staff trained and qualified to act in the consensual pre-procedural and endo-procedural stages.

Another action aimed at transforming culture would be the introduction, in public tenders for careers of the Judiciary, the compulsion of certain numbers of questions about other mechanisms of conflict management.

It is necessary that the Judiciary assimilate that the transformations of the current culture will inexorably generate a loss of importance of the judicial form in managing conflict, generating a greater prominence of the consensual methods, mainly of the negotiations, mediations and extraprocedural conciliations (the resolution of conflicts through an agreement, without using means of adjudication to settle their disputes).

It is also necessary to raise the awareness of the judiciary on the importance of consensual means.

In Santa Catarina, there are reports of magistrates who still maintain the formal structure of the conciliations (reduced time of hearing without possibility of extension or re-designation for

15 Available in: http://www.cnj.jus.br/noticias/judiciario/79202-sancionada-lei-que-regulamenta-trabalho-demediador-e-conciliador. Access in: 27/09/2016. 
continuity; general formula with the mere question of whether the parties have proposed agreements; as well as the refusal to refer disputes to mediation for accredited judicial mediators.

In some situations, the obstacles created by magistrates are explained by personal disbelief in consensual means and by the ideology of believing that consensual means should not be offered by the structure of the Judiciary, but outside it. There is also the problem created by the establishment of goals of the CNJ, in such a way that, judges realize in the conflicts of less complexity the possibility of the fulfillment of these goals and, therefore, they should be solved by sentence. Since meeting these goals are necessary for your future promotions.

2) The professionalization of mediators and conciliators to act both in a pre-procedural way and in the endo-procedural stages is fundamental to the development of a mass of agents (conciliators and mediators) prepared for the adequate use of consensual techniques. It is not enough that the formation and professionalization is carried out only by the Judiciary. Other relevant institutes of the justice system such as public advocacy, public prosecution, state advocacy and even public administration need to transform their way of dealing with conflict management.

Recognizing its peculiarity (for example, the impossibility of their use in issues related to unavailable rights), it is also possible to incorporate consensual practices and create the necessary mechanisms for its development in other spheres of State action, training and updating professionals and creating its own conciliators and mediators staff;

3) The transformation of culture also includes the performance of the professionals of the justice system Organizations. The Brazilian Bar Association (OAB), just as an example, needs to create instruments for the construction and diffusion of a consensual culture of conflict management. Superior schools for Lawyers - ESA (such as schools of magistracy and public prosecutors) are important means for the education of professionals so that they can greatly assist in the transition of culture. To implement this, they can offer the courses necessary for the training and education of lawyers for the use of consensual conflict management techniques. As known, in consensual proceedings, the lawyer's position is important and different from that adopted in adversarial proceedings. Lack of knowledge about the appropriate way of acting may make the lawyer a barrier to the use of consensual means.

Thus, it is necessary that the professional training offered by the Superior School of Lawyer also turns to the education of the lawyer in its action in consensual procedures breaking with the current dominant adversarial position. In a consultation held at the Superior School of Law of Santa Catarina (ESA / SC), for this research, it was found that no course on consensual means of conflict management was offered in the year 2015/2016. On the other hand, 14 face-to-face training courses were organized in the sub-sections (from September to November 2016) with themes related to the civil procedure ${ }^{16}$.

Another important aspect for the transformation of culture is the requirement for the Lawyer Bar Exam (Exame de Ordem), which enables the practice of advocacy, to have a relevant amount of questions about other instruments conflict management (arbitration, mediation, conciliation, etc.);

4) Resolution No. 125 of the CNJ also highlights the importance of the Law Courses in indoctrinating legal practitioners aware of other techniques for conflict management. The current curriculum of law courses contributes to the reproduction of the sentence culture. About 20 to $25 \%$ of the training content of future legal operators highlights the teaching of the process and, consequently, the use of the judicial form as the central pillar of the Brazilian justice system. For Watanabe (2011, p. 5):

\footnotetext{
${ }^{16}$ More information: http://www.esa-sc.org.br/inicio . Access in: 24/09/2016.
} 
[...] strategies for generating the new mentality and culture of pacification, including the creation by law faculties of specific disciplines for training future law professionals in alternative means of conflict resolution, especially mediation and conciliation ${ }^{17}$.

Pozzatti Jr, Maillart and Santos (2015, p. 83-90), analyzing the curriculum of 40 important Law Courses in the states of southern Brazil (Rio Grande do Sul, Santa Catarina, Paraná) and in the State of São Paulo, found that only about one-third of this curriculum have some compulsory discipline with content aimed at teaching other means of conflict management.

It's evident that the mandatory content of other means of conflict management is relevant so that the training of future operators of the law is not in the sense of reproducing the culture of the sentence. However, it is not enough a merely theoretical formation, with a very small workload, to transform the current culture. The training should also involve simulated and real practice, via the Legal Practice Nucleus or continued extension projects, so the student accomplishes the Law Course with sufficient knowledge to act, in different fields, in the use of other methods of conflict management, especially consensual ones.

It is primordial that training and discussion in Law Courses be compatible with the transformation of the current model into a broader culture of conflict management, breaking with the paradigm of judicial superiority as the basis of the Brazilian justice system.

Though, the discussion should not be confined to the curriculum of the graduate Law Courses. Also, in postgraduate studies, whether "lato sensu" or "stricto sensu", the content of a broader administration of conflicts should be encouraged, creating a permanent discussion about the justice model desired in Brazil and the necessary improvements for the system of justice. Disciplines of consensual means, arbitration, restorative justice, among others, must be recognized by Law Courses as relevant in the training and improvement of future law professionals.

There is no doubt that the transformation of culture from sentence culture to a broader (multidoor) culture of conflict management necessarily involves a change in the formation and education of the legal community.

The present research does not pretend to believe that it has identified all obstacles to the establishment of a "consensual culture" and that the proposals indicated above deplete the means that could be used in the transformation of a culture so ingrained.

The proposals put forward propose an extended reflection on the training of the operators of the law and how it is essential to make changes in this training to seek a cultural transformation. There is also no illusion that the change of culture in the legal community is not enough to transform the culture of conflict management.

In addition to the changes that must occur in the legal community, other actions must also be taken so that cultural transformation may affect other institutions. Therefore, it is necessary to disseminate training and education in the use of consensual means to manage important social conflicts, such as: a) neighborhood (neighborhood associations and community associations); b) school conflicts (arising from the relations: server x server, server x student, student x student, etc.); c) conflicts arising from the provision of public services (community vs. public administration or concessionaires). These are some of the social actions that should accompany the changes suggested for the legal community.

\footnotetext{
17 “[...] estratégias para geração da nova mentalidade e da cultura da pacificação, inclusive com criação pelas faculdades de direito de disciplinas específicas para capacitação dos futuros profissionais do direito em meios alternativos de resolução de conflitos, em especial a mediação e a conciliação". Watanabe, 2011, p. 5.
} 
When the CNJ's statistical data show a substantial reduction in the legal and ongoing legal proceedings, with a larger number of cases resolved by agreements (whether through negotiation, mediation or conciliation - extra-judicial or judicial), with a large group of professionals able to properly and professionally operate such consensual methods, it will be possible to believe that the transformation of culture is taking place and that the sentence culture will no longer be the traditional model of conflict management in Brazil, replacing it with a consensual culture.

\section{CONCLUSION}

For Edgerton (2002, p. 197) $)^{18}$, the societies,

[...] they are also capable of preserving social beliefs, values and institutions that result in senseless cruelty, unnecessary suffering and monumental stupidity in their internal relationships with other societies and the physical environment in which they live. People are not always wise, and the societies and cultures that they create are ideal adaptation mechanisms, perfectly designed to meet human needs. It is a mistake to argue, as do many experts, that if a population clings to a traditional belief or practice for many years it necessarily plays a major role in their life. Traditional beliefs and practices may be useful, may even serve as important adaptive mechanisms, but may also be inefficient, harmful, and even lethal.

The above text can be used to reflect on the system of justice that is adopted in Brazil where the resolution of legal conflicts is sent almost exclusively to the judges. Despite the acknowledged problems and sometimes inoperability of a model based on the adjudication solutions, there is still a conformity that allows the continuous reproduction of this system.

This paper had the intention to present considerations about the transformation of the Brazilian legal culture, based on the use of the judicial process and the search for the adjudicated decision ("sentence culture"), for a new model of coexistence, equality and importance among the various methods admitted in the legal system with a focus on consensual mechanisms. Based on this idea, it also sought to reflect on the training of the legal operators and the essential instruments to achieve the desired cultural changes.

For this it was explained, initially, that all genesis occurs with the disparity between mine and yours that conjugates the "our" conflict. In this way, created the conflict, it appears to the people the need to solve it or to administer it.

In Brazil, as in most countries of the West, conflicts are treated predominantly by the traditional model (paradigm) of the judicial form (adjudicated decision), offered by the Judiciary.

\footnotetext{
18 “[...] são capazes também de preservar crenças, valores e instituições sociais que resultam em crueldade sem sentido, sofrimento desnecessário e monumental estupidez em suas relações internas, com outras sociedades e com o ambiente físico onde vivem. As pessoas nem sempre são sábias, e as sociedades e culturas que elas criam são mecanismos de adaptação ideais, perfeitamente projetados para prover as necessidades humanas. É um erro sustentar, como o fazem muitos especialistas, que se uma população se apega a uma crença ou prática tradicional por muitos anos ela necessariamente desempenha papel importante em sua vida. As crenças e práticas tradicionais podem ser úteis, podem até servir como importantes mecanismos de adaptação, mas também podem ser ineficientes, danosas e até letais". Edgerton, 2002, p. 197.
} 
This fact imposes what is referred to in this research as a "sentence culture", that is, in a judicial proceeding, the preponderance of the performance of a third party (judge) charged with declaring, in an enforced and vertical way, who is supposed to belong the right.

The persistence of the Society in this model of decision adjudicated by a judge has implications and consequences, such as: the premature judicialization of all legal problems; a system of justice linked almost exclusively to the judiciary; a relatively time-consuming and costly justice; a predominantly formal justice; an adversarial justice, with little incentive to the cooperation of those who are involved in the conflict.

As known the model of imposition of the sentence by the judge has already been in force in Brazilian culture for a long time. But, currently, according to CNJ data, this way of dealing with demands is bound to inefficiency and, therefore, has been rethought.

Reforms in the Justice System, such as CNJ Resolution 125, which assigns to the Judiciary the duty to include public policies of consensual means; new Code of Civil Procedure, which brought the mediation and conciliation within the judicial process and the regulatory framework of Law 13.140 on mediation, are some of the legislative mechanisms that seek to transform the culture of conflict management in Brazil.

Thus, through the mentioned legislative measures, it is intended to transform the "sentence culture" into a broader model of conflict management, with emphasis on the self-applied path known as "consensus culture".

However, although the legislative changes serve to introduce awareness about the need to change the Justice System in Brazil, such changes cannot be disassociated with other measures, otherwise it will be only a mere discourse of transformation of culture aiming at maintaining its original format.

The lessons of Lampedusa (2002, p. 42) in the classic "The Leopard" are valuable in teaching that sometimes "for things to remain the same, everything must change".

Thus, without there being any changes in the training and practice of legal practitioners, such as judges, prosecutors, lawyers, among others, it will not be possible to think about the transformation of the Justice System, nor into changes in the legal culture of management of conflicts. For this, it is necessary to invest in the education and training of the legal community in all its spheres, as well as to promote the awareness of individuals and social groups about the means available for the administration of conflicts.

Attention should be paid to legal training courses at all levels to break with the traditional view of conflict management and to include learning and dissemination of theoretical and practical disciplines focused on wide means of conflict management.

The students of the Legal Courses, in the development of learning and later in their professional life, must know the tools of each technique of administration of the conflicts. It is necessary that they have sufficient knowledge to, in facing the factual situations brought by the parties, to filter the problem and interests at stake and, later on, to guide people to use the most appropriate means to accomplish their objectives

Thus, it is not intended to disregard the importance of adopting new legislative measures, even though cultural change in the administration of conflicts necessarily reflects the education and alignment of the legal community and society. 


\section{REFERENCES}

ARNAUD, André-Jean; DULCE, Maria José Fariñas. Introdução à análise sociológica dos sistemas jurídicos. Rio de Janeiro-São Paulo: Renovar, 2000.

CAIVANO, Roque J.; GOBBI, Marcelo; PADILLA, Roberto E. Negociación y mediación. Buenos Aires: Ad Hoc, 1997.

CALMON, Petrônio. Fundamentos da mediação e da conciliação. Rio de Janeiro: Forense, 2007.

CAMPANELLA, Tommaso. A cidade do sol. São Paulo: Martin Claret, 2004.

COLUCCI, Claudia. Família pede na justiça que SUS dê remédio de alto custo para cadela. Available in: http://www1.folha.uol.com.br/cotidiano/2016/09/1810929-familia-pede-na-justicaque-sus-de-remedio-caro-para-cadela-doente.shtml. Access in:24/09/2017.

CONSELHO NACIONAL DE JUSTIÇA. Justiça em números 2017: ano base 2016. Brasília : CNJ, $2017 . \quad$ Disponível em http://www.cnj.jus.br/files/conteudo/arquivo/2017/09/904f097f215cf19a2838166729516b79.pdf acesso em 10/09/2017.

CONSELHO NACIONAL DE JUSTIÇA. Relatório 100 maiores litigantes. Brasília : CNJ, 2011. Disponível em:

http://www.cnj.jus.br/images/pesquisas-judiciarias/pesquisa_100_maiores_litigantes.pdf . Acesso em 10/09/2017.

ENTELMAN, Remo F. Teoria de conflictos. Barcelona: Gedisa Editorial, 2005.

ESTADO DE SÃO PAULO. Lei no 15804 de 22 de abril de 2015. Disponível em: http://dobuscadireta.imprensaoficial.com.br/default.aspx? DataPublicacao=20150423\&Caderno= DOE-I\&NumeroPagina=1. Acesso em 27/09/2016.

FUNDAÇÃO GETÚLIO VARGAS. Relatório ICJ Brasil - $1^{\circ}$ semestre 2016. Disponível em: https://bibliotecadigital.fgv.br/dspace/bitstream/handle/10438/17204/RelatorioICJBrasil_1_sem_2016.pdf?sequence=1\&isAllowed=y . Acesso em 10/09/2017.

GRINOVER, Ada Pellegrini. Ensaio sobre a processualidade. Brasília: Gazeta Jurídica, 2016.

GRINOVER, Ada Pellegrini; WATANABE, Kazuo; LAGRASTA NETO, Caetano (Coordenadores). Mediação e gerenciamento do processo. São Paulo: Atlas, 2007.

EDGERTON, Robert B. Crenças e práticas tradicionais: algumas são melhores do que as outras. In HARRISON, Lawrence; HUNTINGTON, Samuel P. A cultura importa. Rio de Janeiro, São Paulo: Record, 2002. 
HIGHTON, Elena I., ÁLVAREZ, Gladys S. Mediación para resolver conflictos. Buenos Aires: Ad-hoc, 1998.

HUXLEY, Aldous. Admirável mundo novo. Disponível em: http://www.fapan.edu.br/media/files/35/35 1372.pdf. Acesso em 10/09/2017.

LAMPEDUSA. O Leopardo. São Paulo: Nova Cultural, 2002.

MITCHELL, C. R. The structure of international conflict. N. York: St. Martin Press, 1989.

MORE, Thomas. Utopia. Disponível em: http://funag.gov.br/loja/download/260-Utopia.pdf . Acesso em 10/09/2017.

POZZATTI JUNIOR, Ademar; MAILLART, Adriana Silva; SANTOS, Ricardo Soares Stersi dos. Reflexões sobre o ensino dos meios alternativos de resolução de conflitos nos cursos de direito. In: MUNIZ, Tânia Lobo; Araújo Junior, Miguel Etinger de. Estudo em direito negocial e os mecanismos contemporâneos de resolução de conflitos. Biriguí: Boreal, 2014, p. 70-96.

OLGUÍN, Miguel Ángel. Solución de conflictos sociales. México: Biblioteca imaginaria, 2002.

REPÚBLICA FEDERATIVA DO BRASIL. Lei n 9099 de 26 de setembro de 1995. Disponível em: http://www.planalto.gov.br/ccivil_03/leis/L9099.htm. Acesso em 27/09/2016.

REPÚBLICA FEDERATIVA DO BRASIL. Lei n 9307 de 22 de setembro de 1996. Disponível em: http://www.planalto.gov.br/ccivil_03/leis/L9307.htm. Acesso em 27/09/2016.

REPÚBLICA FEDERATIVA DO BRASIL. Lei n 13105 de 16 de março de 2015. Disponível em: http://www.planalto.gov.br/ccivil_03/_ato2015-2018/2015/lei/113105.htm. Acesso em $\underline{27 / 09 / 2016 .}$

REPÚBLICA FEDERATIVA DO BRASIL. Lei n 13129 de 26 de maio de 2015. Disponível em: http://www.planalto.gov.br/ccivil_03/_Ato2015-2018/2015/Lei/L13129.htm. Acesso em 27/09/2016.

REPÚBLICA FEDERATIVA DO BRASIL. Lei no 13140 de 26 de junho de 2015. Disponível em: http://www.planalto.gov.br/ccivil_03/_Ato2015-2018/2015/Lei/L13140.htm. Acesso em 27/09/2016.

WEBER, Max. Conceitos básicos de sociologia. São Paulo: Centauro Editora, 2002. 